\author{
Felicjan Bylok \\ Czestochowa University of Technology \\ Faculty of Management \\ e-mail: byl.f.s@zim.pcz.pl
}

\title{
Intricacies of modern consumption: Consumerism vs. deconsumption*
}

\begin{abstract}
The subject of considerations in the paper is a reflection on modern consumption. The author, in search of an answer to the question what main orientations determine consumer behaviour in the market, formulates the hypothesis that deconsumption may become a permanent trend in the development of modern consumption. In order to verify this hypothesis, consumerism along with its main styles and deconsumption as a response to excessive consumption are analysed. The author presents forms of deconsumption, i.e. sustainable consumption, green consumerism, ethical consumption, anti-consumption and consumer movements promoting such forms of consumption. In the conclusions, he points to the development potential of deconsumption manifested in a growing number of consumers who are changing their consumption habits into more socially and environmentally friendly ones.
\end{abstract}

Keywords: consumerism, consumption styles, deconsumption, anti-consumption, sustainable consumption

JEL Classification: M30

\footnotetext{
* The article is an updated version of the paper published in Polish in Annales. Ethics in Economic Life, $19(1), 55-69$.
} 


\section{Introduction}

In highly developed capitalist societies, called consumer societies, focus on the acquisition of an increasing number of new products is dominant. This orientation is supported by manufacturers, profiting from permanent growth in demand for new products, as well as the state, benefiting from taxes on consumer goods and services. Various actions have been taken to encourage people to make purchases, such as marketing campaigns (e.g.: advertising, special offers) and financial solutions stimulating sales (e.g.: lower VAT, preferential loans, etc.). All this leads to the development of hyper-consumption. One should, therefore, agree with the thesis of Zygmunt Bauman (2005) that life in the consumer society consists in the constant acquisition, consumption, use and waste disposal, only to begin everything anew the next day. This kind of behaviour results in, on the one hand, overproduction of consumer goods, and on the other hand, increased environmental risks.

The development of hyper-consumption draws criticism which points to dangers associated with its expansion in the modern world. New forms of behaviour and consumption, in particular, sustainable consumption, voluntary simplicity in consumption, slow life, etc. are becoming widespread.

The main aim of the paper is a reflection on modern consumption. The author seeks an answer to the question what main orientations determine consumer behaviour in the market. In reference to this question, the author formulates the hypothesis that deconsumption may become a permanent trend in the development of modern consumption. In order to verify thus formulated a hypothesis, the literature review method has been used.

\section{Considerations on the concept of consumerism}

Consumerism is a multidimensional concept, hence different researchers point to its various aspects. It is used, firstly, to explain the growing importance of consumption as a factor of social change (Bylok, 2013), secondly, it serves to explain excessive consumption of goods which is related to the insatiable desire to purchase an increasing number of new consumer goods (Sklair, 1991), thirdly, the concept of consumerism is associated with globalisation, in particular, with global culture (Ger \& Belk, 1996), fourthly, consumerism is associated with a certain type of social system (Bauman, 2009), and fifthly, it is recognised as a compass guiding people's lives (Miles, 1998). In all its meanings, consumerism is becoming one of the main factors determining the functioning of an individual in modern society.

Consumerism is becoming a certain way of life which is associated with excessive purchase and consumption of goods. Shopping is considered a characteristic pattern of behaviour. It is understood in the following two ways: as making 
spontaneous purchases in shopping centres or as a form of sensual consumption associated with admiring shop window displays and products in shops without the intention of buying any of them (Hellmann, 2008, p. 36). According to the first interpretation, it can manifest in the form of making a purchase with a specific purpose or without. This sort of shopping has a utilitarian character as it is connected with the acquisition of goods or services necessary to meet one's needs, and it is often seen as a kind of "work". Whereas shopping without a specific purpose is a hedonistic activity in which pleasure and fun are paramount. According to the latter interpretation, shopping means having fun while strolling and browsing in shops. The consumer takes a walk to hear, smell, taste, i.e. to experience a variety of sensations among the exhibits from the world of dreams displayed in shopping centres. Such a consumer becomes a postflaneur, that is, a person who visits shops in order to experience the pleasure of looking at shop displays (Wątroba, 2008, p. 83).

The use of consumption to create one's individual identity is an important element of a lifestyle based on constant consumption of new products. According to Kai-Uwe Hellmann (2008, p. 41), consumerism is a programme that people use for constructing a (post)modernist identity by selecting it from many different options. Such an identity is not expressed in one form; it exists in different variants without any major fundamental differences. An individual can freely choose different identities depending on a social situation. In this case, one can speak of a kind of fluidity of identity.

Consumerism is also understood as an ideology of consumer society which is supposed to deliver new visions of life for people. According to Robert Bocock (1993, p. 48), consumerism is an active ideology that suggests that life is based primarily on the purchase of things and experiencing sensations supplied as part of consumer goods. He indicates that consumption is becoming the most important goal for an individual. Leslie Sklair (2010, p. 135) believes that consumerism is an ideology that contains a set of beliefs and values associated with capitalist globalisation the purpose of which is to persuade people that happiness is best achieved through consumption and possession of goods. Along with global culture, it is becoming one of the main factors causing changes in social life. As noted by Steven Miles (1998, p. 3), consumerism is gaining control over masses of consumers all over the world. It permeates everyday life and structures of people's everyday experience. Due to the continuous change of its form, consumerism is becoming more attractive, increasing its influence over people.

Analysing consumerism, Craig Bartholomew (1988, pp. 6-9) distinguishes its following characteristics. Firstly, he points to a culture of consumption, in which values are associated with consumption, as the basis of consumerism. Secondly, consumerism is equated with an individual choice. Freedom of choice in terms of product, lifestyle or one's identity is the binding principle in the modern consumer society. Thirdly, consumer culture creates needs that seem to be unlimited and at the same time insatiable. Consumerism offers ways to meet these needs, but, oddly enough, there always emerge some new needs, which evoke a sense of insatiability, forcing consumers to find new consumer goods. 
The power of consumerism lies in the fact that it supplies tools (consumer goods and consumption patterns) that are used to create an individual and collective identity for all individuals, at any time and place in the world. The advantage of this ideology is that it offers new forms of social life and identification that are widely available. It can be said that consumerism provides the illusion of equality in inequality, i.e. people have equal access to consumer goods, but only those that have matching funds can actually buy them.

\section{Styles of consumption promoted by consumerism}

Consumerism, despite the fact that it does not have clearly defined objectives or means of dissemination of ideas, is expansive. This expansion is manifested in promoting different styles of consumption that are attractive to people. The most important styles include hedonistic consumption, conspicuous consumption, symbolic consumption and spontaneous consumption. An attempt to describe the most important elements of the individual styles of consumption is presented below.

\subsection{Hedonistic consumption}

In the consumer society, the desire to experience pleasure has become one of the most important goals in people's lives. Consumers not only pose the question of how to achieve something in life but also the question what they expect from life. The answer is a pleasant life, full of adventures and surprises. Gerhard Schulze (1992), in search of an answer to the question about cultural determinants of human life in a welfare society, indicates that the meaning of modern man's life is determined by the desire to experience pleasure and adventure. Consumer goods with a content of pleasure are a means of achieving life goals thanks to which the consumer's life makes sense.

The consequence of this approach is the development of orientation towards pleasure, which means that not the utility functions of a given product, but above all, its symbolic functions have an impact on the act of purchase. From this point of view, the functionality and quality of a given object are important, but what is essential is the hidden potential of satisfying the need for pleasure and adventure. Products with a hidden content of pleasure influence the consumer's subjective sense of satisfaction. The content of pleasure in the product can be its appearance (design), packaging, the material from which it is made, its colour, smell, etc. The semantic content is often associated with hedonistic values, which affects the subjective sense of pleasure. The main source of consumption stimulated by hedonistic values is an imaginary use of dream goods. Products that contain the potential of dreams are the most sought after. However, after buying such goods, consumers lose interest in their purchases because they begin to dream about other goods. Colin Campbell (1987, p. 84) explains this process using a modified consumer choice model: longing - acquisition-use-disappointment. In this model, the need was replaced with longing (dream). Satisfaction of desires is the indicator of achieving pleasure. 
Studies of consumer behaviour show that the consumers' pleasure comes from the search for new products on the market, the pleasure that comes from watching the commercials, admiring display windows and browsing in large shops, as well as through the act of purchase. The group of consumers focused on achieving pleasure consists of individuals who live according to the principle of "novelty is the best," i.e. the best, most fashionable equipment is the kind of good which is the most desirable by this group of consumers. Consumption and practising sports are used to create their identity (Bylok, 2005, pp. 376-378).

To sum up, the growing importance of hedonistic orientation in social life means the creation of a certain collective mentality of hedonism in which the feeling of pleasure is an important indicator of the quality of life.

\subsection{Conspicuous consumption}

In highly developed societies, most people do not have problems with meeting basic needs. Most individuals are focused on their actions on the search for goods that will satisfy their secondary needs associated with social life. One of the main motives of such behaviour is the desire to stand out among others through demonstrating the possession of consumer goods that are considered socially important. This style of consumption can be called conspicuous consumption. For the first time, the manifestations of this type of consumption were described by Thorstein Veblen (1971), who, analysing the nineteenth century society, characterised conspicuous consumption. He pointed out that consumption was a means to gain prestige in the upper class and among the aristocracy. In order for consumption to be appreciated by others, it was necessary to show what one had in excess, what could not be fully consumed, and those goods needed to be visible to individuals with whom one wished to be compared.

In modern society, conspicuous consumption is characterised by the shift in the focus from acquiring and demonstrating goods to experiencing goods and their symbolic image. Customers do not want to emphasise their position through extravagance and high expenses but through more subtle types of market behaviour. In the words of Pierre Bourdieu (2005, p. 237), it can be said that what distinguishes man is taste associated with social class. Taste is an indicator of social class because individual choices, which are based on the principle of taste, are always a form of class practices. Goods associated with consumption patterns through which the consumer communicates his membership in a particular social class are the attributes of his taste. Specific patterns of tastes, consumption preferences and lifestyle practices make it possible to build a map of tastes and lifestyles in a society which to a greater or lesser extent reflects the existing class division. Based on this map, individuals can classify their own tastes and tastes of others to a specific social class.

Conspicuous consumption is associated with the snob effect. It was first described by Leibenstein (1950), who indicated that the consumer who wants to stand out socially when buying goods takes into account, on the one hand, the personal and emotional desire to own prestigious brands, and on the other hand, 
the potential of the impression which a given product can make on other people. The public context of demonstrating the product is important. The greater the audience, the stronger the desire to create a style of consumption that distinguishes one individual from the other. Various events such as concerts, charity balls, theatrical performances and places such as shopping arenas (shopping centres, shopping arcades) are often used for this demonstration.

Today conspicuous consumption still has a significant influence on consumer behaviour not only of members of upper classes but also lower classes. The poorest people also want to stand out socially, which is why they often spend their limited financial resources on luxury goods. Karl H. Hörning (1970) believes that in a situation when low income is accompanied by high-level aspirations, a phenomenon of asymmetry of styles of money spending occurs. A person wanting to belong to the upper class thus makes "immoral appropriation" of goods that are symbols of consumption available to the upper class.

To sum up, in today's society one can point to the duality of forms of conspicuous consumption. On the one hand, there is the development of the strategy of conspicuous consumption of luxury goods, and on the other hand, the strategy of striving for external expression through an individual lifestyle. People want to express their "self" through consumption. With the help of goods with a symbolic content, they can communicate their identity to others.

\subsection{Symbolic consumption}

Another style promoted by consumerism is symbolic consumption aimed at goods with a symbolic content, i.e. those which represent a certain style of life of an individual, a social group or the whole society (Stihler, 1998, p. 204). For a consumer good to be considered a product containing symbolic content, it must have "visibility" (visibilät) and "significance" (signifikant) (Wiswede, 2000, p. 48). "Visibility" means symbols and signs that particularly stand out, while "significance" is unambiguity of distinction as well as a collectively widespread belief about a particular significance of a given good. Visibility and significance endow

goods with a communicative character. For a product to be considered prestigious, it needs to be visible and recognised as long-lasting. In other words, products do not become luxurious in the public mind because of their physical properties but because of their image in society.

Most often, goods with a symbolic content create a specific, consistent set of symbols, e.g.: a lifestyle associated with social roles. Consumer goods with a symbolic content tend to be complementary to each other. Grant McCracken (1998, p. 123) defines this situation as Diderot unity. Symbolic matching of goods is the result of links between cultural categories and categories of goods.

Symbolic consumption means the acquisition of products based on their symbolic value. Symbols connected with social status are becoming less and less important. On the other hand, the importance of the potential of emotions attached to consumer goods is growing. Rifkin describes this phenomenon as "cultural capitalism", in which intangible goods such as experiences or an atmosphere are 
noticeably becoming goods for sale (cf. Ullrich, 2006, p. 46). Schulze (1992, p. 427) also points out to the development of this phenomenon. According to the German sociologist, there is a shift happening from the utility and status symbol value of products to emotional and fictional values. This is the result of the transition from consumption-oriented outwards to inwards oriented consumption. Experiences which the consumer buys are closely associated with goods. For example, there are restaurants that are meant to provide culinary experience, clubs offering unusual attractions, tourist offices selling holidays full of adventures, and shopping centres providing various forms of entertainment. A common feature of these ventures is the offer to provide hitherto unknown to the consumer experiences and a unique atmosphere. In these places, people can fulfil their fantasies. Unusual experiences and an extraordinary atmosphere have become symbols of limitless consumption.

To sum up, in the modern world, symbolic consumption has become an important element of consumerism, stimulating consumer behaviour aimed at purchasing goods with a symbolic and emotional content. Consumers do not seek goods only because of their usefulness but because the products offer an additional symbolic value, e.g., wearing a certain label. The situation is aptly described by Wolfgang Ullrich (2006, p. 45), who indicates that modern developed welfare society is characterised by the transition from the production of goods to the production of the image.

\subsection{Spontaneous consumption}

The next style promoted through consumerism is impulsive consumption which is characterised by irrationality which manifests itself in the spontaneous acquisition of goods. Impulse shopping differs from rational shopping by the fact that decisions about the purchase of a given product are made quickly, under the influence of emotions, and without any in-depth reflection. On the basis of research, Rolf Haubl (1996, p. 218) came to the conclusion that the majority of consumers make purchases on an impulse, though paradoxically "impulse shopping" is planned, but not by the consumer but by the seller. Shop owners arrange a situation in which consumers lose control over their decisions. To this end, they apply various marketing techniques, for example, hospitality, gifts, discounts, etc. In addition, they use shop decorations and attractive music to create a pleasant atmosphere conducive to spontaneous purchases. Manfred Prisching (2009, p. 122) believes that the purpose of the producer and this kind of offer is putting a potential buyer into a trance of consumption which consists in perceiving the world of consumer goods as the most significant. The act of buying becomes a pleasure in itself, a release of psychological stress, a dream come true.

Spontaneous consumption is based on the focus on "here and now". Research on consumer behaviour shows that spontaneous consumers are people making decisions about purchasing a given commercial good on the spur of the moment, without controlling their consumer spending. In the absence of money to buy more expensive, more luxurious items, consumers take a loan or borrow money from 
friends or family. This type of consumer is characterised by a fascination with consumption and focus on "here and now" ("no matter how much it costs I must have it"). Spending money is more important to such individuals than earning it. They often buy things because of their symbolic functions, not paying attention to their utility functions (Bylok, 2005, pp. 375-376).

\section{Deconsumption}

In modern societies, focused on excessive consumption inadequate to actual needs, types of behaviour and attitudes aimed at the moderate consumption of goods and services appear. In this case, one can speak of the creation of a new trend in consumption, the so-called deconsumption, which is becoming an alternative to consumerism. This concept has various definitions in the literature. Annie Leonard and Ariane Conrad (2011, p. 145) understand deconsumption as avoidance of excess, which is an important step towards "conscious consumption". Deconsumption is defined by Czesław Bywalec and Leszek Rudnicki (2002, p. 143) as a conscious limitation of consumption to a rational size, arising from natural, individual, physical and mental characteristics of the consumer. Elżbieta Szul (2012, p. 318) sees deconsumption as rational, conscious, responsible and ethical consumption. Its slogan is "less is more".

Deconsumption is connected with the limitation of previous excessive consumption for various reasons, such as an economic crisis, a lifestyle change, increased uncertainty, greater awareness related to responsibility, an ethical approach to consumption, etc. It can take various forms, such as sustainable consumption, green consumerism, ethical consumption, anti-consumption and movements promoting reduced consumption. The most often described form deconsumption is sustainable consumption. There are three ways of defining the category of sustainable consumption: as an alternative way of life, as ecoconsumption and as a holistic approach (Dąbrowska et al., 2015, pp. 83-84). The first approach assumes the departure from the current form of consumption focused primarily on meeting secondary needs. The basic tenets of this approach include: living in small self-sufficient communities in order to minimise the environmental impact associated with transport, limiting the fulfilment of needs to the minimum required for survival, and taking action against those that cause environmental degradation. The second approach assumes that the main goal should be ecological consumption (eco-consumption). The conceptualisation of this notion is based on the assumption that environmental protection can be achieved by increasing demand for environmentally friendly products. From this point of view, the key to sustainable consumption is an increase in rational and informed environmental attitudes and types of behaviour based on deep values (Ottman, 2003). When making the decision about choosing a particular product, the consumer takes into account not only the fulfilment of personal desires and satisfaction but also the consequences for the natural environment. According to Rob Harrison, 
Terry Newholm and Deirdre Shaw (2005, p. 2), at the time of purchase of goods, the eco-consumer is not taking into consideration him or herself, but, above all, the surrounding world. The third approach, holistic, assumes that the consumer when deciding on purchasing a particular product takes into account not only its environmental impact but also its social (including human rights, e.g.: fair wages for employees), inter-generational and economic impact. A change in consumer behaviour aimed at sustainable consumption is becoming more and more popular given the rise of awareness associated with responsible consumption.

Green consumerism is associated with involvement in environmental activities. The operational definition of green consumerism includes a list of actions that are taken to promote a positive impact on the natural environment. The most important of these are purchasing energy-saving equipment, buying green products, turning off electrical appliances when not in use, or taking shorter showers to save water (Sachdeva, Jordan \& Mazar, 2015, pp. 60-65). It is also assumed that ecoconsumers' choices are not always made only on the basis of the alleged positive consequences for the environment. For example, purchasing decision concerning organic food items may be also affected by such factors as taste, quality or health (Grunert, Hieke \& Wills, 2014).

Ethical consumption is associated with the idea of promoting ethical values in consumer behaviour. As shown by Andrew Crane and Dirk Matten (2007), the essence of the concept of ethical consumption is the conscious and deliberate decision to make consumer choices based on personal moral convictions and ethical values. Ethical behaviour includes the kind of conduct in which the consumer is guided by ethical values in the process of acquiring, using and disposing of products. It can manifest in reducing consumption of goods associated with a consumption-oriented lifestyle, caring about the natural environment, boycotting manufacturers not complying with labour rights, supporting fair trade, etc. In the discussion on ethical consumption, issues related to fair trade, fair pay, observance of human rights by companies producing consumer goods, non-employment of children, the scale of pollution and post-consumer waste, animal welfare, etc. are important.

Anti-consumption can be understood as the abandonment of forms of consumption that are typical of the so-called western way of life and the acceptance of such forms that are environmentally friendly (Black \& Cherrier, 2010, p. 439). The concept of anti-consumption is associated with refraining from consumption of certain products and brands that are considered harmful to the environment but also represents a kind of lifestyle which allows individual expression and provides a sense of self-esteem and self-efficacy (Zavestoski, 2002). It is also a way of life typical of subcultures, for example, political movements whose aim is the destruction of the formal political structure.

Consumer social movements play an important role in the dissemination of deconsumption-related ideas. The most important of such movements are environmental ones which promote pro-environmental consumption. Ecological consumption is an element of eco-consumption consumer movement whose aim is to stop through changes in the sphere of consumption negative processes degrading 
the natural environment and deteriorating the quality of human life. This movement postulates changes that should take the form of the rational use of consumer goods; adopting an attitude consistent with the principles of environmental protection; consuming ecological goods (mainly food); limiting consumption of goods that create dangerous post-consumer waste; preferring consumption of goods that "generate" small amounts of post-consumer waste; reducing the use of resources and energy used for the production of consumer goods, and minimising consumption of natural resources through the use of clean consumer goods manufacturing techniques (Bylok, 2013, pp. 224-228).

Another social movement that promotes the ideas of sustainable consumption is the movement of voluntary simplicity in consumption whose goal is the reduction of material consumption and changing the current lifestyle through "removing the clutter from one's life" into a way of life based on simplicity associated with the reduction of purchase of many unnecessary consumer goods (Ballantine \& Creery, 2010). In general, the movement seeks to limit the purchase of goods and encourages the use of alternative consumption possibilities, for example, the use of second-hand products, focus on the usefulness of purchased goods rather than on their number, the exchange of goods and services between consumers, which allows them to build new channels of communication, and the creation of consumer communities. People who adopt a lifestyle based on voluntary simplicity are to varying degrees involved in activities aimed at limiting consumption. Firstly, their actions can be associated with the resignation from certain consumer goods (for example, the ones considered a luxury) while retaining the current consumer lifestyle; secondly, a significant limitation of current consumption and a change in the current way of life; and thirdly, adapting life patterns to the ethos of simplicity. People who adopt this form of lifestyle move from more affluent areas to small towns, rural areas, or farms with the aim of pursuing a simpler life (Etzioni, 1998, pp. 620-623). Limitation of this movement is its relatively small scope that includes only highly developed countries in which its members belong most often to middle-class and middle-upper class (Belk \& Ger, 2011). Relatively fewer members come from lower social classes.

Another consumer movement worth presenting is ethical consumerism promoting ethical consumption in which treating a purchase as an ethical choice plays an important role. Consumers connected with this movement seek to make people aware of global consequences of excessive consumption, make them pay attention to the conditions in which products are manufactured and to their composition, as well as promote companies that comply with human rights and labour rights (LewickaStrzałecka, 2003, p. 136).

Anti-consumption understood as a withdrawal from forms of consumption that are typical of the so-called western way of life and the adoption of such forms that are environmentally friendly, has been dynamically developing (Black \& Cherrier, 2010). This movement is based on the assumption that consumerism is a threat to the spirituality and system of values of modern man. The forms of activities related to this movement include: firstly, the organisation of radical consumer boycotts, secondly, the rejection of the ownership of goods, the withdrawal 
from the world of consumption and living in a kind of communes, the so-called squats, which become centres of promoting a way of life based on anticonsumption, and thirdly, the spread of new models of consumer behaviour, for example, the self-manufacture of goods or repair of goods owned, giving up car transport in favour of riding a bike, the rejection of the consumption of products made of living beings, dumpster diving and the acquisition of goods without paying (shop lifting) (Portwood-Stacer, 2012, p. 92).

The effectiveness of actions carried out by consumer movements in order to limit consumption threatening the natural environment largely depends on their forms of impact on producers. As Pope Francis (2015, p. 164) notes in his encyclical on environmental issues, consumer movements that manage to make sure that some products are not purchased effectively change the functioning of enterprises, forcing them to consider their impact on the environment and to rethink their production models.

All the presented forms of deconsumption are characterised by the desire to rationalise people's actions in the area of consumption. This process promotes the growth of consumer awareness related to the perception of the threat to the environment and lasting interpersonal relations resulting from excessive consumption.

\section{Conclusions}

A reflection on contemporary consumption leads to a conclusion about the existence of a paradox. The spread of consumerism in the poor societies is becoming increasingly attractive. At the same time, an awareness of excessive consumption is also developing in a new orientation, the deconsumption. Despite many indications of a change in the views on modern consumption, consumerism, which offers a mirage of happiness and pleasant life in the world of consumption, remains the most important orientation. The main result of consumer behaviour under the influence of consumerism is the lack of moderation in purchasing, i.e., "consumption for consumption's sake".

Is there an alternative to lifestyles promoted by consumerism? It would seem that sustainable consumption may be such an alternative. Along with the increase in excessive consumption, criticism of consumerism manifested in the pursuit of moderation in the acquisition of new products as well as in the search for and consumption of goods that do not harm the environment, can be observed. People who articulate such attitudes take as a reference point values related to responsibility and fairness. This morality impacts the formation of the attitude of coresponsibility of the consumer for the degradation of the environment. The social doctrine of the Church takes a firm stance on this issue. Pope Francis routinely criticises excessive consumption leading to environmental degradation. He emphasises the need to "replace consumption with sacrifice, greed with generosity, wastefulness with a spirit of sharing, an asceticism which entails learning to give, and not simply to give up" (2015, p. 9). 
In conclusion, a gradual increase in the number of consumers who, aware of the harmful effect that excessive consumption has on the natural environment, will be changing their consumer habits into ones that are friendly towards the environment and other people can be expected.

\section{References}

Ballantine, P. W., \& Creery, S. (2010). The Consumption and Disposition Behaviour of Voluntary Simplifiers. Journal of Consumer Behaviour, 9(1), 45-56.

Bartholomew, C. (1988). Christ and Consumerism: An Introduction. In C. Bartholomew, \& T. Moritz (Eds.), Christ and consumerism. Critical reflections on the spirit of our age. Carlisle: Paternoster Publishing.

Bauman, Z. (2005). Życie na przemiał. Kraków: Wydawnictwo Literackie.

Bauman, Z. (2009). Konsumowanie życia. Kraków: Wydawnictwo Uniwersytetu Jagiellońskiego.

Belk, R. W., \& Ger, G. (2011). Consumption in affluent societies. In E. F. Moran (Ed.), Encyclopedia on Sustainable Development. UNESCO. http://www.eolss.net/sample -chapters/c11/e1-11-07-03.pdf

Black, I. R., \& Cherrier, H. (2010). Anti-consumption as part of living a sustainable lifestyle: daily practices, contextual motivation and subjective values. Journal of Consumer Behaviour, 9(6), 437-453.

Bocock, R. (1993). Consumption. London: Routledge.

Bourdieu, P. (2005). Dystynkcja. Społeczna krytyka władzy sqadzenia (P. Biłos, Trans.). Warszawa: Wydawnictwo Naukowe Scholar.

Bylok, F. (2005). Konsumpcja w Polsce i jej przemiany w okresie transformacji. Częstochowa: Wydawnictwo Politechniki Częstochowskiej.

Bylok, F. (2013). Konsumpcja, konsument i społeczeństwo konsumpcyjne we wspótczesnym spoleczeństwie. Studium socjologiczne. Katowice: Wydawnictwo Naukowe "Śląsk".

Bylok, F. (2016). Meandry konsumpcji we współczesnym społeczeństwie: konsumpcjonizm versus dekonsumpcja. Annales. Ethics in Economic Life, 19(1), 55-69.

Bywalec, C., \& Rudnicki, L. (2002). Konsumpcja. Warszawa: Polskie Wydawnictwo Ekonomiczne.

Campbell, C. (1987). The romantic ethic and the spirit of modern consumerism. London: Basil Blackwell Publisher.

Crane, A., \& Matten, D. (2007). Business Ethics. Oxford University Press.

Dąbrowska, A., Bylok, F., Janoś-Kresło, M., Kiełczewski, D., \& Ozimek, I. (2015). Kompetencje konsumentów - innowacyjne zachowania, zrównoważona konsumpcja. Warszawa: Polskie Wydawnictwo Ekonomiczne.

Etzioni, A. (1998). Voluntary simplicity: Characterization, select psychological implications and societal consequences. Journal of Economic Psychology, 19(55), 619-643.

Ger, G., \& Belk, R. W. (1996). I'd like to buy the world a coke: Consumption-scapes of the "Less Affluent World". Journal of Consumer Policy, 19(3), 271-304. 
Grunert, K. G., Hieke, S., \& Wills, J. (2014). Sustainability labels on food products: Consumer motivation, understanding and use. Food Policy, 44, 177-189.

Harrison, R., Newholm, T., \& Shaw, D. (2005). Pressure groups, campaigns and consumers. In R. Harrison, T. Newholm, \& D. Shaw (Eds.), The ethical consumer. London: Sage.

Haubl, R. (1996). "Welcome to the Pleasure Dome" Einkaufen als Zeitvertrieb. In H. A. Hartmann, \& R. Haubl (Eds.), Freizeit in der Erlebnisgesellschaft. Amüsement zwischen Selbstverwirklichung und Kommerz, Auflag 1. Wiesbaden: Westdeucher Verlag.

Hellmann, K.-U. (2008). Das konsumistische Syndrom. In K.-U. Hellman, \& G. Zurstiege (Eds.), Räume des Konsums über den Funktionswandel von Räumlichkeit im Zeitalter des Konsumismus. Wiesbaden: VS Verlag für Sozialwissenschaften.

Hörning, K. H. (1970). Ansätze zu einer Konsumsoziologie. Feiburg: Verlag Rombach.

Leibenstein, H. (1950). Bandwagon, Snob, and Veblen Effects in the theory of conspicuous demand. Quarterly Journal of Economics, 64(2), 183-207.

Leonard, A., \& Conrad, A. (2011). The story of stuff: The impact of overconsumption on the planet, our communities, and our health - and how we can make it better. New York: Free Press.

Lewicka-Strzałecka, A. (2003). Konsumeryzm versus konsumeryzm. Annales. Etyka $w \dot{Z} y c i u$ Gospodarczym, 6, 132-138.

McCracken, G. (1988). Culture and consumption. New approaches to the symbolic character of consumer goods and activities. Bloomington/Indianapolis: Indiana University Press.

Miles, S. (1998). Consumerism - as a way of life. London: Sage.

Ottman, J. A. (2003). Green marketing: Challenges and opportunities for the new marketing age. Lincolnwood: NTC Business Books.

Pope Francis (2015). Encyklika Laudato SI’ Ojca Świętego Franciszka poświęcona trosce o wspólny dom. https://w2.vatican.va/content/dam/francesco/pdf/en-cyclicals/docume nts/papa-francesco_20150524_enciclica-laudato-si_pl.pdf

Portwood-Stacer, L. (2012). Anti-consumption as tactical resistance: Anarchists, subculture, and activist strategy. Journal of Consumer Culture, 12(1), 87-105.

Prisching, M. (2009). Die zweidimensionale Gesellschaft. Ein Essay zur neokonsumistischen Geisteshaltung. Wiesbaden: VS Verlag für Sozialwisenschaft.

Sachdeva, S., Jordan, J., \& Mazar, N. (2015). Green consumerism: moral motivations to a sustainable future. Current Opinion in Psychology, 6, 60-65.

Schulze, G. (1992). Die Erlebnisgesellschaft. Kultursoziologie der Gegenwart. Frankfurt/M: Verlag Campus.

Sklair, L. (1991). Sociology of the Global System. Baltimore: Johns Hopkins University Press.

Sklair, L. (2010). Iconic architecture and the culture-ideology of consumerism. Theory, Culture \& Society, 27(5), 135-159.

Stihler, A. (1998). Die Entstehung des modernen Konsums. Darstellung und Erklärungsansätze. Berlin: Duncker und Humbold.

Szul, E. (2012). Dekonsumpcja - moda czy sposób na kryzys. Nierówności Społeczne a Wzrost Rospodarczy, 24, 316-328. 
Ullrich, W. (2006). Habenwollen. Wie funktioniert die Konsumkultur? Frankfurt am Main: S. Fischer Verlag.

Veblen, T. (1971). Teoria klasy próżniaczej. Warszawa: Państwowe Wydawnictwo Naukowe.

Wątroba, W. (2008). Homo postmillenius. Wrocław: Wydawnictwo Uniwesytetu Ekonomicznego we Wrocławiu.

Wiswede, G. (2000). Konsumsoziologie - Eine vergessene Disziplin. In D. Rosenkranz, \& N. F. Schneider (Eds.), Konsum: soziologische, ökonomische und psychologische Perspektiven. Opladen: Verlag Leske + Budrich.

Zavestoski, S. (2002). The social-psychological bases of anticonsumption attitudes. Psychology \& Marketing, 19(2), 149-165. 